\begin{tabular}{|c|c|c|}
\hline Beitr. Ent. & Keltern & ISSN 0005-805X \\
\hline $\mathbf{6 2}(2012) 1$ & S. $69-76$ & 15.05 .2012 \\
\hline
\end{tabular}

\title{
Biology of leaf gall-inducing Thlibothrips manipurenis MuraleEdharan, 1982 on Ardisia sp. (Myrsinaceae) in north- eastern India
}

\section{(Thysanoptera: Tubulifera: Phlaeothripidae)}

With 11 figures

\author{
Heishnam Taptamani, Ramaiyer Varatharajan and Anantanarayanan Raman
}

\begin{abstract}
Summary
Biology of the epiphyllous roll-gall-inducing Thlibothrips manipurensis was studied on Ardisia sp. under laboratory conditions. T. manipurensis laid eggs linearly along the margins of tender leaves. Eggs hatched in $6.8 \mathrm{~d}$ and the larval duration was 3.4 and $8.2 \mathrm{~d}$ for larvae I and II, respectively. After $20.2 \mathrm{~h}$ as prepupa, T. manipurensis grew into pupa; adult emergence occurred in $4 \mathrm{~d}$. Each female laid $34 \pm 7$ eggs and the mean longevity of the adult was $10.2 \mathrm{~d}$. Increase in thrips numbers correlated with the age of the gall: 15 individuals/gall occurred in young ( $4-10 \mathrm{~d})$ galls, whereas 28 occurred in mature $(20 \mathrm{~d})$ galls, and 36 in old ( $25 \mathrm{~d})$ galls. Male-female ratio in old galls was 1:5. Mature galls included a homogeneous tissue structure, made of 12-15 layers of parenchyma cells with no distinction into spongy and palisade cells. The gall-mesophyll cells adjacent to the upper and lower epidermises developed essentially through anticlinal divisions of the primordial cells, whereas those in mid regions developed through periclinal divisions; the latter facilitates the blade to roll inwards. Cells in the mid region of the galled lamina were larger than those occurring adjacent to the epidermises. Bulk of the cells in the mid-region of the galled lamina included darkly staining inclusions, which, in high likelihood, were phenolic materials. Thliobothrips is an ally of Gynaikothrips. Thlibothrips and Gynaikothrips are the better known gall-inducing taxa. The roll galls induced by Thlibothrips manipurensis on Ardisia sp. (Myrsinaceae, Asterids, Eudicots) are highly similar to those induced by Gynaikothrips flaviantennatus on the leaves of Casearia elliptica (Salicaceae: Samydeae, Rosids, Eudicots) in southern India. Because the Rosids and Asterids are considered related phylogenetically, the possible pathways taken by species of Gynaikothrips and Thlibothrips to radiate exploring different, but related plant taxa appear striking.
\end{abstract}

\section{Zusammenfassung}

Die Biologie der Rollgallen induzierenden Thlibothrips manipurensis wurde auf Ardisia sp. unter Laborbedingungen untersucht. T. manipurensis legt linear Eier entlang der Ränder der jungen Blätter von Ardisia sp. Die Eier schlüpften in 6,8 d und das Larvalstadium dauerte 3,4 und 8,2 d für Larven I und II. Das Vorpuppenstadium bis zur Vollendung der Verpuppung betrug für T. manipurensis 20,2 Stunden. Nach $4 \mathrm{~d}$ begann das Erwachsenenstadium. Jedes Weibchen legte $34 \pm 7$ Eier und die durchschnittliche Lebensdauer der Erwachsenen (adulten Tiere) betrug 10,2 d. Die Anzahl der Thripse korreliert mit dem Alter der Gallen: 15 Thripse/Galle ist bei jungen (4-10 d) Gallen gefunden, während es 28 in reifen $(20 \mathrm{~d})$ Gallen und 36 in alten (25 d) Gallen waren. Das Männchen/Weibchen-Verhältnis in alten Gallen war 1:5. Reife Gallen enthalten eine homogene Gewebestruktur, die aus 12-15 Schichten der Parenchym Zellen besteht, wobei es keinen Unterschied gibt zwischen Schwamm- und Palisaden-Zellen. Die Mesophyll-Zellen in den Gallen grenzen an die obere und untere Epidermis und entwickeln sich im Wesentlichen durch anticlinale Teilung der primordialen Zellen, während diejenigen in der mittleren Region sich durch periclinale Teilung entwickeln. Die letztere erleichtert das Einrollen. In der mitteleren Region waren die Zellen 
der Gallen-Lamina größer als diejenigen der angrenzenden Epidermis. Der Großteil der Zellen in der Mitte der Gallen-Lamina enthielt in Safranin-Lichtgrün-Färbung dunkel erscheinende Einschlüsse, die mit hoher Wahrscheinlichkeit phenolische Materialien waren. Thliobothrips ist ein Verwandter von Gynaikothrips. Thlibothrips und Gynaikothrips sind die am besten bekannten Gallen induzierenden Taxa. In Südindien sind die Roll-Gallen von Thlibothrips manipurensis in Ardisia sp. (Myrsinaceae, Asteriden, Eudikotyledonen) denen sehr ähnlich, die durch Gynaikothrips flaviantennatus in Blättern der Casearia ellipitca (Salicaceae: Samydeae, Rosiden, Eudikotyledonen) induziert werden. Die Rosiden, Eudikotyledonen sind phylogenetisch ähnlich. Die möglichen Wege von Gynaikothrips und Thlibothrips, verschiedene aber verwandte Pflanzentaxa zu befallen, sind bemerkenswert.

\section{Key words}

Ardisia sp., galls, marginal-leaf rolls, Myrsinaceae, Phlaeothripidae, population patterns through development, Thlibothrips manipurensis, Thysanoptera, Tubulifera

\section{Introduction}

Thlibothrips Priesner, 1951 belongs to Gynaikothrips-Liophlaeothrips-Liothrips complex (sensu Ananthakrishnan \& MuraleEdharan 1974). It is distinguished by elongated fusiform eighth antennal segment and enlarged posterior ommatidia. Seven species of Thlibothrips are known today (Mound 2007). Thlibothrips isunoki OKajIma, 1981 and T. nigricauda (Karny, 1915) are the confirmed gall-inducing taxa on the leaves of Symplocos myrtacea SiEBold et ZucCarini, 1870 (Symplocaceae) (Haga et al. 1989) and Drypetes sepiaria (Wight et Arnold) Pax et K. Hoffmann, 1922 (= Hemicyclia sepiaria Wight et Arnold, 1833) (Euphorbiaceae) (ANANTHAKrishnan 1978), respectively. Thlibothrips atavus (KARNY, 1915), T. antennalis OKajIMA, 1981, T. primitivus (Karny, 1922), T. malloti Ananthakrishnan, 1961, and T. manipurensis Muraleedharan, 1982 have been recorded as associates in undetermined galls; their role - whether inducers or inquilines - in galls was not established (ANANTHAKRISHNAN 1978). The present paper confirms the role of T. manipurensis as the inducer of the marginal-roll galls on the leaves of a possible new species of Ardisia Swartz, 1910 (suspected to be near Ardisia paniculata Roxburgh, 1824 - a common taxon on north-eastern India, DeVI \& YADAVA 2006), with notes on their populations during gall development.

\section{Materials and Methods}

Leaves of Ardisia sp. bearing young ( $4-10 \mathrm{~d})$, mature $(20 \mathrm{~d})$, and old ( $>25 \mathrm{~d})$ galls, and stages showing gall initiation ( $0-3 \mathrm{~d}$ ) were collected randomly from Moréh (Chandel district, Manipur, India, $300 \mathrm{amsl}$, $24^{\circ} 40^{\prime} \mathrm{N} ; 93^{\circ} 50^{\prime} \mathrm{E}$ ) in the Indo-Myanmar biodiversity hotspot of north-eastern India in August 2009, based on previous field observations that the life cylce of T. manipurensis is completed in $25-28 \mathrm{~d}$ (TAPTAMANI \& VARATHARAJAN, unpublished observations). The collected materials were transported to the Life-Sciences laboratory of Manipur University at Canchipur (c. $90 \mathrm{~km}$ from Moréh) in polythene bags stored in a transportable ice chest. In the laboraory, galls in different developmental stages were unrolled carefully under a stereobinocular microscope (Olympus Magnus MS 24/13, No. 5D 0347, Olympus India, New Delhi, India) for obtaining population data of different development stages of T. manipurensis. Eggs laid along the partly in-rolled margins of tender leaves were counted. Cut ends of gall-bearing branches were stood in glass jars containing tap water. Galled leaves were enclosed individually in polythene bags with pinholes to permit aeration. The bags were tightened at pedicel points to prevent thrips escape. The polythene bags were carefully opened every day to dry accumulated moisture, to count numbers of moulted larvae, pupae, 
and adults, and to assess brood sizes. Five such cultures were maintained in the laboratory $\left(18 \pm 2^{\circ} \mathrm{C} \mathrm{min}\right.$, $26 \pm 1.5^{\circ} \mathrm{C} \max , 72 \pm 5 \% \mathrm{RH}, 12: 12 \mathrm{~L}: \mathrm{D}$ ). Numbers (mean $\pm \mathrm{SE}$ ) of different life stages of T. manipurensis from the maintained cultures were obtained.

To establish the relationship between gall size and brood size, 15 tender leaves of Ardisia sp. with their pedicels, after ensuring that each leaf included at least one gravid female of T. manipurnesis, were individually stood in tap-water cultures in the laboratory, enabling galls to grow. In $25 \mathrm{~d}$, every gall maintained in water culture, was unrolled to assess the brood size. Fifteen mature and old galls were measured from leaf tip to pedicel using a scientific centimetre ruler. The data pertaining to gall size versus brood size were recorded from each culture and then processed for Pearson-correlation analysis using the Statistical Package for Social Sciences (2001, 11.5 software; http://www.spss.com; Chicago).

Microtome sections were prepared from similar-aged leaves (i) those bearing galls and (ii) those did not (hereafter referred as 'normal') from determined sheets of Ardisia sp. near paniculata stored in the herbarium of the School of Life Sciences, Manipur University. Leaf materials were revived by boiling them for $60 \mathrm{~min}$ in water added with a few drops of commercial detergent and glycerol. Revived materials were sliced $\left(3 \mathrm{~mm}^{2}\right)$ and fixed FAA $(70 \%$ alcohol $90 \mathrm{ml}$, formalin $5 \mathrm{ml}$, acetic acid $5 \mathrm{ml})$. Fixed specimens were processed for microtomy, following protocols described in BRADBURY (1973). The $10 \mu \mathrm{m}$ sections obtained were mounted on glass slides and stained with safranin-fast green combination, mounted in DPX, and photographed (Olympus Trinocular Research Microscope, CX 31, Camera E-520, Manila, The Philippines).

\section{Results}

The earliest infestation by T. manipurensis on the leaves of Ardisia sp. in Moréh, under field conditions occurred in August 2009 and earliest stages of 'galls' included 2-3 adults/leaf, with at least one adult female on each infested leaf. On an average, 15 individuals $(11 \pm 1$ larvae and $4 \pm 1$ pupae)/gall occurred in young galls, 28 (13.5 \pm 1 larvae, $8.5 \pm 1$ pupae, and $6 \pm 1$ adults)/gall in mature galls, and $36(3.5 \pm 0.5$ larvae, $3.5 \pm 0.5$ pupae, and $29 \pm 2$ adults $) /$ gall in old galls. The sex ratio in $25 \mathrm{~d}$ old galls was $1: 5\left(\sigma^{*}:\right.$ : $)$.

Thlibothrips manipurensis laid eggs linearly along the adaxial edges of tender leaves, with their edges showing early signs of rolling commencing from the leaf tip (Fig. 1). Eggs hatched in $6.8 \mathrm{~d}$; larval duration was 3.4 and $8.2 \mathrm{~d}$ for larvae I and II, respectively. After $20.2 \mathrm{~h}$ as prepupa, T. manipurensis grew into pupa and adult emergence occurred in $4 \mathrm{~d}$. Each female laid $34 \pm 7$ eggs and the mean longevity of the adult was $10.2 \mathrm{~d}$ (Figs 1-6). The gravid female laid the first batch of eggs $(4.8 \pm 0.8)$ on the third day of adult eclosion on the adaxial side of tender leaves and guarded her eggs until larval emergence. On the fifth day, the second batch of eggs $(8.2 \pm 0.7)$ was laid. Meanwhile the already started rolling extended towards the pedicel

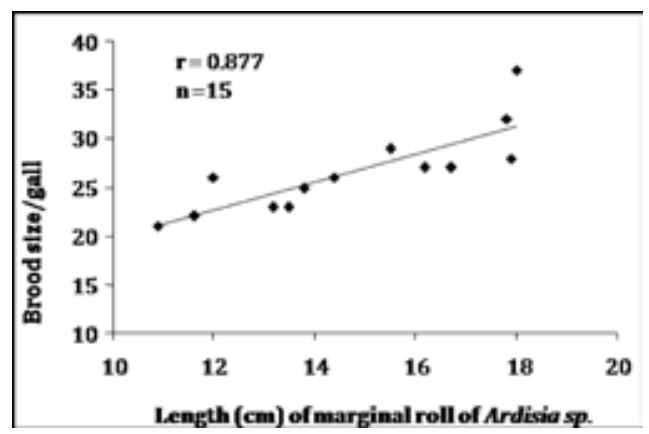

Fig. 7: Relation between length of marginal roll and brood size (offspring numbers) of $T$. manipurensis. of the infested leaf, with several individuals of T. manipurensis feeding at those points. Subsequently, each female laid $4.4 \pm 1$ eggs/day from $\mathrm{d} 6$ to 10 . However, brood size depended on the length of the leaf roll. Length measurements of old galls (added value of galls along both edges of the same leaf blade) revealed that $18.3 \pm 2 \mathrm{~cm}$ long galls included $34 \pm 2$ eggs, whereas $15.3 \pm 1 \mathrm{~cm}$ long galls included $27 \pm 2$ eggs, and $12.2 \pm 0.4 \mathrm{~cm}$ long galls $23 \pm 2$ eggs. Fig. 7 illustrates the relationship between the two tested variables and also that the brood size is directly dependent 
on gall length $(\mathrm{r}=0.877, p<0.01, \mathrm{n}=15)$. Mating period was $10-20 \mathrm{~min}$ and they displayed a wing-combing and grooming behaviour (Ellington 1980, Varatharajan 1984, Mound \& MORris 2001) using their mid and hind legs.

All gall-bearing leaves, maintained under laboratory conditions, from initiation stage included only populations of T. manipurensis. Neither in the samples obtained from the field nor in the laboratory cultures we could observe any other taxon that was either a predator or a parasitoid or an inquiline. Each mature gall $(n=15)$ included $13.5 \pm 1$ larvae, $8.5 \pm 1$ pupae, and $6 \pm 1$ adults of T. manipurensis, whereas each old gall included $3.5 \pm 0.5$ larvae, $3.5 \pm 0.5$ pupae, and $29 \pm 2$ adults. More individuals of T. manipurensis occurred in the inner roll, until the $25 \mathrm{~d}$ of gall growth. Thereafter adults started moving out of the gall and occupied either the corners of polythene bag or the partly dry leaf areas.

Thlibothrips manipurensis induce galls (Fig. 8) on the leaves of Ardisia sp., wherein the blades roll towards the midrib on the upper side. Mature normal leaves showed a dorsiventrally differentiated structure with one layer of short palisade cells and 5-6 layers of spongy mesophyll (Fig. 9). Mature galls included a homogeneous tissue structure, made of 12-15 layers of parenchyma cells with no distinction into spongy and palisade cells (Fig. 10). The mesophyll cells lying close to the upper and lower epidermises in mature galls developed essentially through anticlinal divisions of the primordial cells, whereas those in the mid regions developed through periclinal divisions. Cells in the mid region of the galled leaf blade showed a greater level of cell enlargement than those occurring close to the epidermises. The periclinal divisions and hypertrophied cells in the mid regions of the galled leaf blade enabled rolling. Bulk of the cells in the mid-region of the gall leaf blade included darkly staining cell inclusions, which, in high likelihood are phenolic substances (Fig. 11).

\section{Discussion}

Thlibothrips is an ally of Gynaikothrips (ZIMMERMann, 1900) and Litotetothrips PRIESNER, 1929 (Окалгма 1981). Gynaikothrips and Thlibothrips are the better known gall-inducing taxa, whereas Litotetothrips is an established non-gall-inducing taxon. Gynaikothrips australis BAGNALL, 1929, G. ficorum (Marchal, 1908), and G. uzeli Zimmermann, 1900 induce leaf-fold galls on Ficus macrophylla Desfontaines ex. Persoon, 1807, F. microcarpa Linnæus, 1781 (= F. retusa Linnæus, 1767), and F. benjamina Linnæus, 1767 (Moraceae), respectively, especially in warmer parts of the world (Ananthakrishnan \& Raman 1989), whereas G. flaviantennatus Moulton, 1929 induces roll galls on the leaves of Casearia elliptica Willdenow, 1799 (= C. tomentosa Roxburgh, 1832) (formerly under Samydaceae, now under Salicaceae [Samydeae] sensu Breteler 2008) - a widely occurring taxon in the Indian subcontinent (RAMAN et al. 1978). Mature galls induced by Thlibothrips manipurensis on the leaves of Ardisia sp. are closely similar to those induced by $G$. flaviantennatus on C. tomentosa, in terms of their gross morphology and tissue organization.

A majority of known gall-inducing insects demonstrate a high degree of orientation to specific trophic niches and display a high level of fidelity to particular species of plants (RAman 1996, 2010). Salicaceae and Moraceae are presently treated under Rosids (Eudicots), whereas Myrsinaceae under Asterids (Eudicots); Rosids and Asterids are considered to be related phylogenetically (Angiosperm Phylogeny Group 2003). This indicates how species of Gynaikothrips and Thlibothrips have possibly adapted to radiate among taxa of the Rosids and Asterids, exploring varied ecological niches. 
That T. manipurensis completes its life cyle in 20-25 d matches with the noted biologies of many other Indian Phlaeothripidae: Crotonothrips dantahasta Ramakrishna, 1928, G. flaviantennatus, Schedothrips orientalis (ANANTHAKrishnan, 1968), and Teuchothrips longus (Schmutz, 1913), which induce leaf-roll galls on Memecylon edule RoxBurgh, 1798 (Melastomataceae), C. tomentosa, Ventilago madraspatana GÆRTner, 1788 (Rhamnaceae), and Pavetta zeylanica (Ноok. F.) GAmble, 1921 (= P. hispidula Wight et ARNold, 1880) (Rubiaceae), respectively (ANANTHAKRISHNAN \& RAMAN 1989). Besides being closely similar to the galls induced by $G$. flaviantennatus, the external and internal morphologies of galls induced by T. manipurensis are also similar to those induced by $S$. orientalis and T. longus on the leaves of $V$. madraspatana and $P$. hispidula, respectively. Mature galls induced by $G$. flaviantennatus, S. orientalis, and T. longus also include densely staining secondary compounds (RAMAN \& ANANTHAKRISHNAN 1983), similar to those that occur in galls induced by T. manipurensis. Another striking example is the leaf-roll gall induced by Alocothrips hadrocerus (Karny, 1926) (Phaleothripidae: Phlaeothripinae) on Maytenus senegalensis (Lamarck) Exell, 1952 (Celastraceae), but structures of the galls induced by $A$. hadrocerus differ from those induced by T. manipurensis, S. orientalis, and T. longus. Galls induced by $A$. hadrocerus include mutilple layers of sclereids (RAMAN \& ANANTHAKRISHNAN 1979, RAman 2011a), which are absent in the galls induced by T. manipurensis, S. orientalis, and T. longus. Given that sclereid differentiation is regulated by sugar-hormone modulation (UGGLA et al. 2001) and also that the physical feeding action among Phlaeothripidae is considerably similar (RAMAN 2011b), the preceding comparison points to that the salivary composition of T. manipurensis, S. orientalis, and T. longus is different from that of $A$. hadrocerus. The saliva of T. manipurensis, S. orientalis, and T. longus includes no molecular-trigger factor capable of altering the sugar-hormone modulation in their respective leaf environments, and thus modify the mesophyll parenchyma to differentiate into sclereids.

Margins of tender leaves of Ardisia sp. (0-3 d) already showed signs of rolling, when examined for eggs, similar to the behaviour of Sacothrips corycidis Mound, 1971 (Phaleothripidae: Phlaeothripinae) inducing leaf-margin roll galls on Geijera parviflora LINDLEY, 1848 in eastern parts of subtropical Australia (Mound 1971). Such a response in the leaves of Ardisia indicates that the gravid females of T. manipurensis trigger gall induction by their feeding action before oviposition. In the present study we have shown that gall lengths correlate with brood sizes of T. manipurensis. Although our findings align with the present understanding that the morphology of thrips-induced galls is regulated by the impact of feeding thrips populations documented data (CREspi et al. 1997, RAman 2003, 2010, 2011a), we refer to Laurence Mound's remark (email 21 December 2010) that a majoirty of thrips-induced galls on Acacia in Australia reach their maximum size before oviposition. This reinforces the need for a reconsideration of the effects of brood size of thrips on gall morphology; the gravid female in high probability initiates the gall, similar to the behaviour in the gall-inducing Sternorrhyncha (ROHFRITSCH 1992).

Leaf galls induced by Gynaikothrips ficorum and G. australis on subtropical-Australian Ficus microcarpa and F. macrophylla, respectively, include either the kleptoparasitic Mesothrips jordani Zimmermann, 1900 or the inquilinous Gynaikothrips additamentus (KARNY) Mound, 2008 (Tree \& WaLter 2009). Leaf galls induced by Gynaikothrips uzeli on Ficus benjamina are commonly invaded by predatory Androthrips ramachandrai KARNY, 1926 (Phlaeothripidae: Phaleothripinae) in tropical Asia (Ananthakrishnan 1978) and the Americas (Boyd \& Held 2006, CamberoCAmpos et al. 2010). Why any such predatory, parasitic, and/or inquilinous thrips does not occur in T. manipurensis-induced galls on Ardisia sp. in Manipur, which are similar open systems with the gall chamber communicating with external environment, is unclear. Probably Thlibothrips manipurensis also discharges volatile compounds (e.g., ß-myrcene) similar to T. isunoki that induces galls on the leaves of Symplocos myrtacea in Japan that repel invading arthropods and restrict contamintaing fungi (SUZUKI et al. 2004). 


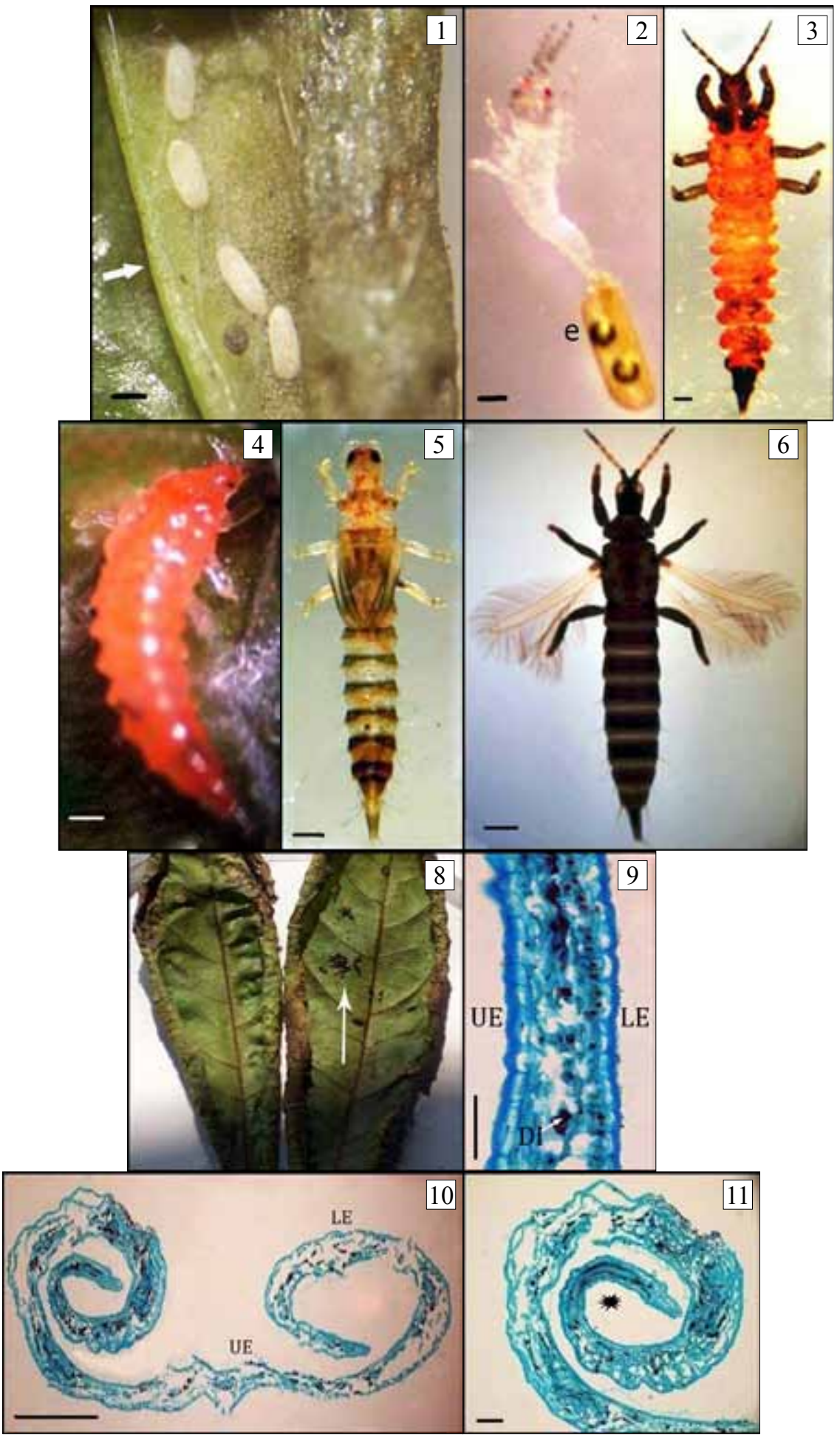




\section{Acknowledgements}

We are grateful to Taracad N. Ananthakrishnan (Minneapolis, USA) and Laurence A. Mound (CSIRO, Canberra, Australia) for reading the draft and offering highly useful remarks, to Marja Simpson (Charles Sturt University, Orange, NSW, Australia) for checking the Zusammenfassung, and to Raja Ponnuchamy (Institut Français de Pondichéry, Pondicherry, India) for verifying plant names. HT and RV thank the Head of School of Life Sciences (Manipur Univesity) for facilities.

\section{Literature}

Ananthakrishnan, T. N. 1978: Thrips Galls and Gall Thrips. - Zoological Survey of India (Technical Monograph) 1: 1-69.

Ananthakrishnan, T. N. \& Raman, A. 1989: Thrips and Gall Dynamics. - New Delhi: Oxford \& IBH Publishing Co.: 120 pp.

Ananthakrishnan, T. N. \& Muraleedharan, N. 1974: Studies on the Gynaikothrips-LiophlaethripsLiothrips complex from India. - Oriental Insects (Supplement) 4: 1-85.

Angiosperm Phylogeny Group, the 2003: An update of the Angiosperm Phylogeny Group classification for the orders and families of flowering plants: APG II. - Botanical Journal of the Linnean Society 141: 399-436.

Boyd, D. \& HeLd, D. W. 2006: Androthrips ramachandrai (Thysanoptera: Phlaeothripidae): an introduced thrips in the United States. - Florida Entomologist 89: 455-458.

Bradbury, S. 1973: Peacock's Elementary Microtechnique (Fourth edition). - Oxford: Pembroke College: 352 pp.

Breteler, F. J. 2008: A synopsis of Casearia JACQ. (Samydeae-Salicaceae) in West and Central Africa with a description of a new species from Eastern Congo (Kinshasa). - Kew Bulletin 63: 101-112.

Cambero-Campos, J.; Valenzuela-García, R.; Carvajal-Cazola, C.; Rios-Velasco, C. \& GarcíaMartínez, O. 2010: New Records for Mexico: Gynaikothrips uzeli, Androthrips ramachandrai (Thysanoptera: Phlaeothripidae) and Montandoniola confusa (Hemiptera: Anthocoridae). - Florida Entomologist 93: 470-472.

Crespi, B. J.; Carmean, D. A. \& Chapman, T. W. 1997: Ecology and evolution of galling thrips and their allies. - Annual Review of Entomology 42: 51-71.

Devi, L. S. \& Yadava, P. S. 2006: Floristic diversity assessment and vegetation analysis of tropical semievergreen forest of Manipur, North East India. - Tropical Ecology 47: 89-98.

Ellington, C. P. 1980: Wing mechanics and take-off preparation of thrips (Thysanoptera). - Journal of Experimental Biology 85: 129-136.

Haga, K.; Suzuki, J.; Kodama, S. \& Kawahara, Y. 1989: Secretion of thrips VI. Identification of ß-myrcene from Thlibothrips isunoki (Thysanoptera: Phlaeothripidae). - Applied Entomology and Zoology 25: 138-139.

Mound, L. A. 1971: The complex of Thysanoptera in rolled leaf galls on Geijera. - Journal of Australian Entomological Society 10: 83-97.

Mound, L. A. 2007: Thysanoptera (Thrips) of the world - a checklist. - http: www.ento.csro.au/thysanoptera/worldthrips.html (accessed on 7 December 2010).

Figs 1-6: Life stages of T. manipurensis. Fig. 1. Eggs along the margin of a joung leaf; arrow - inward rolling of the blade (Bar: $-500 \mu \mathrm{m})$. Fig. 2. Emerging larva; e - egg) (Bar: $500 \mu \mathrm{m})$. Fig. 3. Larva II. (Bar: $-500 \mu \mathrm{m})$. Fig. 4. Prepupa (Bar: $-200 \mu \mathrm{m})$. Fig. 5. Pupa (Bar: $-220 \mu \mathrm{m})$. Fig. 6. Adult (Female). (Bar: $-200 \mu \mathrm{m})$.

Figs 8-11: Normal and T. manipurnesis-infested leaves of Ardisia sp. Fig. 8. infested mature galled leaf (Bar $-1 \mathrm{~cm}$ ); arrow - thrips colony. Fig. 9. Normal leaf (C.S.): DI - dark inclusions (likely phenolics); LE - lower epidermis; UE - upper epidermis (Bar $-100 \mu \mathrm{m}$ ). Fig. 10. Galled leaf (C.S.): LE - lower epidermis; UE - upper epidermis (Bar $-800 \mu \mathrm{m})$. Fig. 11. A portion of the leaf roll enlarged; * - larval chamber (Bar $-100 \mu \mathrm{m})$. 
Mound, L. A. \& Morris, D. C. 2001: Domicile constructing phlaeothripine Thysanoptera from Acacia phyllodes in Australia: Dunatothrips Moulton and Sartrithrips gen. n., with a key to associated genera. - Systematic Entomology 26: 401-419.

Oкаjıмa, S. 1981: The genus Thlibothrips Priesner of leaf-rolling Phlaeothripdiae (Thysanoptera). Transactions of the Shikoku Entomological Society 15: 141-150.

Raman, A. 1996: Nutritional diversity in gall-inducing insects and their evolutionary relationships with flowering plants. - International Journal of Ecology and Environmental Sciences 22: 133-143.

Raman, A. 2003: Cecidogenetic behaviour of some gall-inducing thrips, psyllids, coccids, and gall midges, and morphogenesis of their galls. - Oriental Insects 37: 359-413.

Raman, A. 2010: Patterns of adaptive radiation and diversifaction in cecidogenous insects. Pp. 153-178. - In: Ananthakrishnan, T. N. (ed.): Insect Biodiversity: Functional Dynamics and Ecological Perspectives. Jodhpur: Scientific Publishers.

Raman, A. 2011 a: Morphogenesis of insect-induced plant galls: facts and questions. - Flora 206: 517-533.

Raman, A. 2011b: Gall-inducing behaviour in hemipteroid insects. Pp. 34-70. - In: Ananthakrishnan, T. N. (ed.): Dynamics of Insect Behaviour. Jodhpur: Scientific Publishers.

Raman, A. \& Ananthakrishnan, T. N. 1979: On the developmental morphology of the leaf-fold galls of Maytenus senegalensis (LAM) ExelL, (Celastraceae) induced by Alocothrips hadrocerus KARNY (Thysanoptera: Insecta). - Proceedings of the Indian Academy of Sciences 88: 103-107.

Raman, A. \& Ananthakrishnan, T. N. 1983: Studies on some thrips (Thysanoptera: Insects) induced galls. 1. Developmental morphology. - Proceedings of the Indian National Science Academy B49: 525-561.

Raman, A.; Ananthakrishnan, T. N. \& Swaminathan, S. 1978: On the simple leaf galls of Casearia tomentosa Roxв. (Samydaceae) induced by Gynaikothrips flavianttenatus Moulton (Thysanoptera: Phlaeothripidae). - Proceedings of the Indian Academy of Sciences 87B: 231-242.

Rohfritsch, O. 1992: Patterns in gall development. Pp. 60-86. - In: Shorthouse, J. D. \& Rohfritsch, O. (eds) Biology of Insect-induced Galls. New York: Oxford University Press.

Suzuki, T.; Haga, K.; Tsutsumi, T. \& Matsuyama, S. 2004: Analysis of anal secretions from phlaeothripine thrips. - Journal of Chemical Ecology 30: 409-415.

Tree, D. J. \& Walter, G. H. 2009: Diversity of host plant relationships and leaf galling behaviours within a small genus of thrips - Gynaikothrips and Ficus in south east Queensland, Australia. - Australian Journal of Entomology 48: 269-275.

Uggla, C.; Magel, E.; Moritz, T. \& Sundberg B. 2001: Function and dynamics of auxin and carbohydrates during earlywood/latewood transition in Scots pine. - Plant Physiology 125: 2029-2039.

Varatharajan, R. 1984: Studies on the Bioecology of Anthophilous Thrips of Southern India. Ph. D. thesis, Madras: University of Madras: $132 \mathrm{pp}$.

\section{Authors' addresses:}

Dr. Heishnam Taptamani

Department of Life Sciences

Manipur University

Imphal 795 003, India

e-mail: tapta18jan@gmail.com
Subject editor:

Prof. Ramaiyer Varatharajan

Department of Life Sciences

Manipur University

Imphal 795 003, India

e-mail: rvrajanramya@gmail.com

\section{Dr. Anantanarayanan Raman}

Charles Sturt University \& E H Graham

Centre for Agricultural Innovation

PO Box 883

Orange, NSW 2800, Australia

e-mail: araman@csu.edu.au 